Agata Marcysiak ${ }^{1}$

Uniwersytet Przyrodniczo-Humanistyczny w Siedlcach

Adam Marcysiak ${ }^{2}$

Uniwersytet Przyrodniczo-Humanistyczny w Siedlcach

\title{
Zakres różnicowania poziomu wsparcia gospodarstw środkami Wspólnej Polityki Rolnej UE
}

\section{RANGE OF DIFFERENTIATION OF THE SUPPORT LEVEL OF FARMS WITH MEANS OF THE COMMON AGRICULTURAL POLICY OF THE EU}

\begin{abstract}
Celem niniejszego opracowania jest próba ukazania zakresu różnicowania poziom wsparcia gospodarstw środkami Wspólnej Polityki Rolnej UE. Szczegółowej analizie poddano płatności bezpośrednie i płatności dla obszarów o niekorzystnych warunkach gospodarowania $(O N W)$. Ich wielkość rozpatrywano w relacji do dochodu z gospodarstwa rolniczego. Obliczeń dokonano metoda stosowanq w europejskim systemie rachunkowości rolnej FADN (Farm Accountancy Date Network). Udziat środków pochodzqcych z WPR w analizowanych gospodarstwach w 2015 roku w relacji do dochodu wynosit 37,5\%. Istotnymi elementami różnicujacymi poziom wsparcia gospodarstw środkami Wspólnej Polityki Rolnej UE okazały sie wielkość ekonomiczna i typ rolniczy gospodarstwa. Podstawowymi elementami wsparcia ze środków WPR UE byly płatności realizowane w ramach doptat bezpośrednich i płatności dla obszarów o niekorzystnych warunkach gospodarowania. Stanowity one w 2015 roku odpowiednio $70,7 \%$ i $10,5 \%$ ogólnego wsparcia.
\end{abstract}

Słowa kluczowe: dopłaty bezpośrednie, zróżnicowanie, dochód z gospodarstwa rolniczego, typ rolniczy.

\section{Wprowadzenie}

Przystąpienie Polski do Unii Europejskiej otworzyło nowe szanse rozwiązywania wielu problemów ekonomicznych i społecznych. Integracja z UE zasadniczo zmieniła sposób kreowania i prowadzenia polityki wobec wsi. Nastapiła zmiana otoczenia instytucjonalnego, wymuszając dostosowania przepisów prawa krajowego do regulacji unijnych i budowę systemu instytucji wspierających rozwój wsi i rolnictwa zgodnie z wymaganiami UE ${ }^{3}$.

Po wejściu do UE Polska stała się pełnoprawnym uczestnikiem i beneficjentem mechanizmów Wspólnej Polityki Rolnej w ramach jej dwóch filarów. Na koniec 2015 roku

\footnotetext{
${ }^{1}$ Katedra Ekonomii, Wydział Nauk Ekonomicznych i Prawnych

${ }^{2}$ Katedra Logistyki, Wydział Nauk Ekonomicznych i Prawnych

${ }^{3}$ I Nurzyńska: Polska wieś i rolnictwo jako beneficjenci funduszy Unii Europejskiej. (w:) Polska wieś 2016.

Raport o stanie wsi. Wydawnictwo SCHOLAR, Warszawa 2016, s. 107-127.
} 
udział skumulowanych transferów z budżetu UE w ramach WPR wyniósł 39,2 mld euro, w tym z tytułu dopłat bezpośrednich 21,5 mld euro, a z tytułu programów rozwoju obszarów wiejskich - 16,2 mld euro. Wśród głównych celów jakie stawia sobie WPR można wymienić stabilizację rynku rolnego, wielofunkcyjny rozwój obszarów wiejskich oraz zapewnienie rolnikom odpowiedniego poziomu dochodów i warunków życia ${ }^{4}$.

Konieczność modernizacji i restrukturyzacji polskiego sektora rolno-spożywczego znalazła wyraz w procesach kształtowania polityki wobec obszarów wiejskich, w zmianie zakresu dopuszczalnej pomocy publicznej w sektorze, stosowanych instrumentach finansowych czy organizacji udzielania pomocy. Konsekwencja tego było powstanie systemu rolnych agencji płatniczych, które w Polsce uprawnione są na podstawie posiadanych akredytacji do realizowania płatności na rzecz beneficjentów pomocy unijnej dla wsi i rolnictwa.

Instytucją o takim charakterze i zadaniach stała się Agencja Restrukturyzacji i Modernizacji Rolnictwa. Realizując programy pomocy dla rolnictwa i obszarów wiejskich w ramach 13 kampanii naborów wniosków z przeznaczeniem na wsparcie bezpośrednie

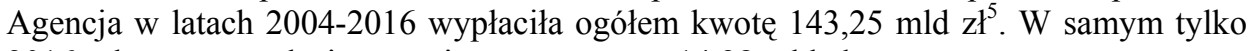
2016 roku na ten rodzaj wsparcia przeznaczono 14,28 mld zł.

Istotnym obszarem oddziaływania instrumentów WPR stały się dochody rolników. Obok tradycyjnych (konwencjonalnych) czynników je kształtujących, takich jak: fizyczne rozmiary produkcji, ponoszone nakłady, relacje cen rolnych, pojawiły się płatności bezpośrednie oraz płatności z tytułu uczestnictwa w programach rolno-środowiskowych i modernizacyjnych ${ }^{6}$. Na przestrzeni lat rola tych transferów w kształtowaniu dochodów rolników niepomiernie wzrosła.

\section{Metodyczne aspekty opracowania}

Celem niniejszego opracowania jest próba ukazania zakresu zróżnicowania poziom wsparcia gospodarstw środkami WPR UE.

Materiałem badawczym były dane o gospodarstwach, które prowadziły rachunkowość rolną dla potrzeb Instytutu Ekonomiki Rolnictwa i Gospodarki Żywnościowej. Szczegółową analizą objęto rok 2015.

Podstawową kategorią ekonomiczna, przyjęta dla potrzeb procesu badawczego, był poziom dochodu $\mathrm{z}$ gospodarstwa rolniczego Obliczeń tej kategorii dokonano metodą stosowaną w europejskim systemie rachunkowości rolnej FADN (Farm Accountancy Date Network $)^{7}$.

Wielkość wsparcia gospodarstw środkami UE analizowano w zależności od wielkości ekonomicznej i typu rolniczego gospodarstwa. Szczegółowej analizie poddano płatności bezpośrednie i płatności dla obszarów o niekorzystnych warunkach gospodarowa-

\footnotetext{
${ }^{4}$ C. Klimkowski, M. Gruda: Podział i transfer dochodów między rolnictwem a gospodarką narodową. Program Wieloletni 2015-2019 IERiGŻ, Warszawa 2016, s. 26-40.

${ }^{5}$ Informacja z realizacji zadań Agencji Restrukturyzacji i Modernizacji Rolnictwa w 2016 roku. Departament Analiz Działalności i Rozwoju ARiMR, Warszawa 2017, s. 7-15.

${ }^{6}$ I. Frenkel: Zatrudnienie i struktura dochodów w gospodarstwach rolnych w latach 205-2010. IRWiR PAN, Warszawa 2013, s. 55-68.

${ }^{7}$ Z Floriańczyk, B. Malanowska, D. Osuch, M. Bocian: Opis realizacji planu wyboru próby gospodarstw rolnych dla Polskiego FADN. IERiGŻ, Warszawa 2017, s. 8-15.
} 
nia. Ich wielkość rozpatrywano w relacji do dochodu z gospodarstwa rolniczego. Poszczególne wielkości ukazano w przeliczeniu na jedno gospodarstwo w zł. Skalę zróżnicowania przedstawiono $\mathrm{w}$ ujęciu procentowym.

\section{Oddziaływanie wielkości ekonomicznej na zakres wsparcia gospodarstw środkami pochodzącymi z WPR UE}

Wielkość ekonomiczna gospodarstw rolnych określana jest sumą Standardowych Produkcji uzyskanych ze wszystkich działalności rolniczych występujących w danym gospodarstwie rolnym i wyrażana jest bezpośrednio w euro. Pole obserwacji Polskiego FADN obejmuje gospodarstwa rolne o minimalnej wielkości ekonomicznej 4000 euro $^{8}$.

Średni obszar badanego gospodarstwa w 2015 roku wynosił 19,4 ha UR. Analizowane gospodarstwa reprezentowały różną wielkość ekonomiczną. W próbie badawczej polskiego FADN liczącej 12313 gospodarstw ${ }^{9}$ dominującymi były gospodarstwa małe o wielkości ekonomicznej 8-25 tys. Euro. Ich udział wynosił 33,1\%. Równie liczną była grupa gospodarstw średnio małych o wielkości ekonomicznej 25-50 tys. Euro $(31,0 \%)$. Gospodarstwa średnio duże (50-100 tys. Euro) i duże (100-500 tys. Euro) stanowiły odpowiednio $21,0 \%$ i $9,2 \%$. Stosunkowo najmniejszy udział posiadały gospodarstwa bardzo małe (do 8 tys. Euro - udział 4,8\%) i bardzo duże (powyżej 100 tys. Euro udział $0,9 \%$ ). W tej ostatniej grupie znajdowały zarówno gospodarstwa indywidualne, jak i te posiadające osobowość prawną.

W odniesieniu do badanych gospodarstw widoczna była zależność, iż wraz ze wzrostem wielkości ekonomicznej gospodarstw zwiększała się powierzchnia UR. Gospodarstwa o wielkości ekonomicznej do 8 tys. Euro liczyły średnio 8,0 ha. W przypadku gospodarstw o wielkości ekonomicznej 50-100 tys. Euro ich obszar wynosił 44,7 ha.

Obszar jest tradycyjnym miernikiem wielkości gospodarstwa rolnego powszechnie uznawanym w literaturze przedmiotu ${ }^{10}$. Powierzchnia użytków rolnych gospodarstwa determinuje kształtowanie się podstawowych relacji produkcyjnoekonomicznych, co w efekcie znajduje odzwierciedlenie w uzyskiwanych dochodach.

Dokonany podział na grupy wydzielone ze względu na wielkość ekonomiczną pozwolił ukazać zakres zróżnicowania sytuacji dochodowej w badanych gospodarstwach (rysunek 1).

\footnotetext{
${ }^{8}$ Z. Florianczyk, B Malanowska, D. Osuch, M. Bocian: Opis realizacji planu wyboru próby gospodarstw rolnych dla Polskiego FADN w 2015 roku. IERiGŻ, Warszawa 2015, 9-15.

${ }^{9}$ Wyniki Standardowe 2015 uzyskane przez gospodarstwa rolne uczestniczące w Polskim FADN. IERiGŻ, Warszawa 2016, s. 41-54.

10 J.S. Zegar B. Chmielewska: Dochody ludności wiejskiej: źródła, zróżnicowanie i zakres ubóstwa. (w:) Raport o stanie wsi. Polska wieś 2016. Wyd. Naukowe SCHOLAR, Warszawa 2016, s. 129-149.
} 


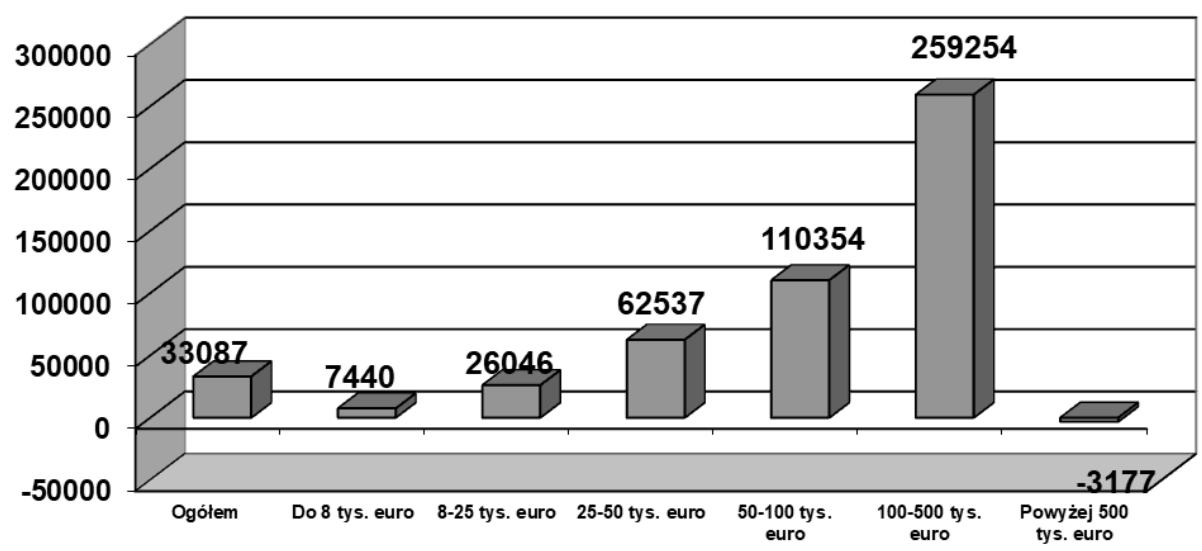

Rysunek 1. Poziom dochodu z gospodarstwa rolniczego według wielkości ekonomicznej w 2015 roku [w zł] Źródło: obliczenia własne na podstawie Wyniki Standardowe 2015 uzyskane przez gospodarstwa rolne uczestniczące w Polskim FADN. IERiGŻ, Warszawa 2016, s. 51-57.

Poziom dochodu pochodzącego $\mathrm{z}$ działalności rolniczej w gospodarstwach prowadzących rachunkowość rolną dla potrzeb IERiGŻ w 2015 roku wynosił średnio 33087 zł. W przeliczeniu na 1 ha UR była to kwota 1706 zł. W gospodarstwach o wielkości ekonomicznej do 8 tys. Euro ta kategoria dochodu wynosiła 7440 zł. Poziom dochodu pochodzącego $\mathrm{z}$ działalności rolniczej w gospodarstwach o wielkości ekonomicznej 50-100 tys. Euro wynosił już 110354 zł. Niestety w gospodarstwach o wielkości ekonomicznej powyżej 500 tys. Euro w 2015 roku pojawiła się strata. Do zbilansowania przez przychody poniesionych kosztów zabrakło tutaj 3177 zł.

Wielkość płatności bezpośrednich do gruntów rolnych w gospodarstwach prowadzących rachunkowość rolną dla potrzeb IERiGŻ w 2015 roku wynosiła średnio 8772 zł. Udział tych płatności w ogólnej kwocie środków Wspólnej Polityki Rolnej UE przekazywanych do tych gospodarstw stanowił 70,7\%. Dla porównania w 2013 udział ten wynosił 79,5\%.

Zakres zróżnicowania poziomu płatności bezpośrednich do gruntów rolnych analizowanych gospodarstw w zależności od wielkości ekonomicznej gospodarstwa przedstawia tabela 1 .

Tabela 1. Wielkość wsparcia środkami WPR UE według wielkości ekonomicznej gospodarstwa w roku 2015

\begin{tabular}{|l|c|c|c|c|c|c|c|c|c|}
\hline \multirow{2}{*}{ Wyszczególnienie } & & \multicolumn{7}{|c|}{ Wielkość ekonomiczna gospodarstwa } \\
\cline { 2 - 9 } & Ogółem & $\begin{array}{c}\text { do } 8 \\
\text { tys. } \\
\text { Euro }\end{array}$ & $\begin{array}{c}8-25 \\
\text { tys. } \\
\text { Euro }\end{array}$ & $\begin{array}{c}25-50 \\
\text { tys. } \\
\text { Euro }\end{array}$ & $\begin{array}{c}50-100 \\
\text { tys. } \\
\text { Euro }\end{array}$ & $\begin{array}{c}100-500 \\
\text { tys. } \\
\text { Euro }\end{array}$ & $\begin{array}{c}\text { powyżej } \\
500 \text { tys. } \\
\text { Euro }\end{array}$ \\
\hline $\begin{array}{l}\text { Płatności bezpośrednie do grun- } \\
\text { tów rolnych }\end{array}$ & 8772 & 3638 & 6821 & 12092 & 20242 & 46884 & 327747 \\
\hline Płatności z tytułu ONW & 1297 & 789 & 1246 & 1821 & 2321 & 3252 & 3727 \\
\hline Płatności rolno-środowiskowe & 1254 & 590 & 1153 & 1812 & 2769 & 6858 & 23168 \\
\hline $\begin{array}{l}\text { Inne dopłaty do rozwoju obsza- } \\
\text { rów wiejskich }\end{array}$ & 1083 & 414 & 1545 & 1522 & 1213 & 690 & 1512 \\
\hline
\end{tabular}




\begin{tabular}{|ll|l|l|l|l|l|l|l|}
\hline $\begin{array}{l}\text { Łącznie środki } \\
\text { ramach WPR UE }\end{array}$ & wypłacane w & 12406 & 5431 & 10765 & 17247 & 26545 & 57684 & 356154 \\
\hline
\end{tabular}

Źródło: obliczenia własne na podstawie Wyniki Standardowe 2015 uzyskane przez gospodarstwa rolne uczestniczące w Polskim FADN. IERiGŻ, Warszawa 2016, s. 51-57.

Średnia wielkość środków pochodzących z płatności bezpośrednich w gospodarstwach o wielkości ekonomicznej do 8 tys. Euro wynosiła 3638 zł. Wraz ze wzrostem wielkości ekonomicznej gospodarstwa rosła także wielkość płatności bezpośrednich do gruntów rolnych. W gospodarstwach o wielkości ekonomicznej 50-100 tys. Euro ta forma płatności wynosiła $20242 \mathrm{zl}$, a w gospodarstwach o wielkości ekonomicznej powyżej 500 tys. Euro aż 327747 zł. Wynikało to ze zróżnicowania obszarowego gospodarstw.

Istotnym elementem oddziaływania ze strony Wspólnej Polityki Rolnej UE jest wsparcie działalności rolniczej na obszarach o niekorzystnych warunkach gospodarowania. Ma ono na celu udzielenie pomocy finansowej gospodarstwom rolnym położonym na terenach, na których produkcja rolnicza jest utrudniona ze względu na warunki naturalne. Płatności przyznawane dla gospodarstw z tytułu ONW mają przeciwdziałać wyludnianiu się obszarów wiejskich i zatracaniu ich rolniczego charakteru.

Wielkość płatności z tytułu ONW w gospodarstwach prowadzących rachunkowość rolną dla potrzeb IERiGŻ w 2015 roku wynosiła średnio 1297 zł. Również i w tym przypadku wielkość ekonomiczna okazała się czynnikiem różnicującym wysokość tej płatności.

W gospodarstwach o wielkości ekonomicznej do 8 tys. Euro średnia kwota płatności z tytułu ONW wyniosła 789 zł. Wraz ze wzrostem wielkości ekonomicznej gospodarstwa rosła także wielkość płatności z tytułu ONW. W gospodarstwach o wielkości ekonomicznej 50-100 tys. Euro ta forma płatności wynosiła $2321 \mathrm{zl}$

Poza środkami z płatności bezpośrednich i płatności z tytułu ONW do analizowanych gospodarstw trafiały także dopłaty rolno-środowiskowe oraz dopłaty do rozwoju obszarów wiejskich. Kwoty przypadające z tych źródeł średnio na gospodarstwo wynosiły w 2015 roku odpowiednio 1254 zł i 1083 zł. Najwyższe kwoty płatności rolnośrodowiskowych otrzymały gospodarstwa o wielkości ekonomicznej powyżej 500 tys. Euro (23168 zł). W przypadku dopłat do rozwoju obszarów wiejskich największe kwoty skierowano do gospodarstw małych o wielkości ekonomicznej 8-25 tys. Euro (średnio na gospodarstwo $1545 \mathrm{zt})$.

Środki przekazywane w ramach Wspólnej Polityki Rolnej nie pozostają obojętne na poziom dochodów pochodzących z produkcji rolniczej. W odniesieniu do analizowanych gospodarstw ogólna kwota wsparcia w ramach WPR UE w 2015 roku stanowiła $37,5 \%$ dochodu z gospodarstwa rolniczego. Spośród różnych form pomocy najbardziej istotne oddziaływanie na sytuację dochodową rolników miały płatności bezpośrednie do gruntów rolnych oraz płatności z tytułu ONW (rysunek 2). 


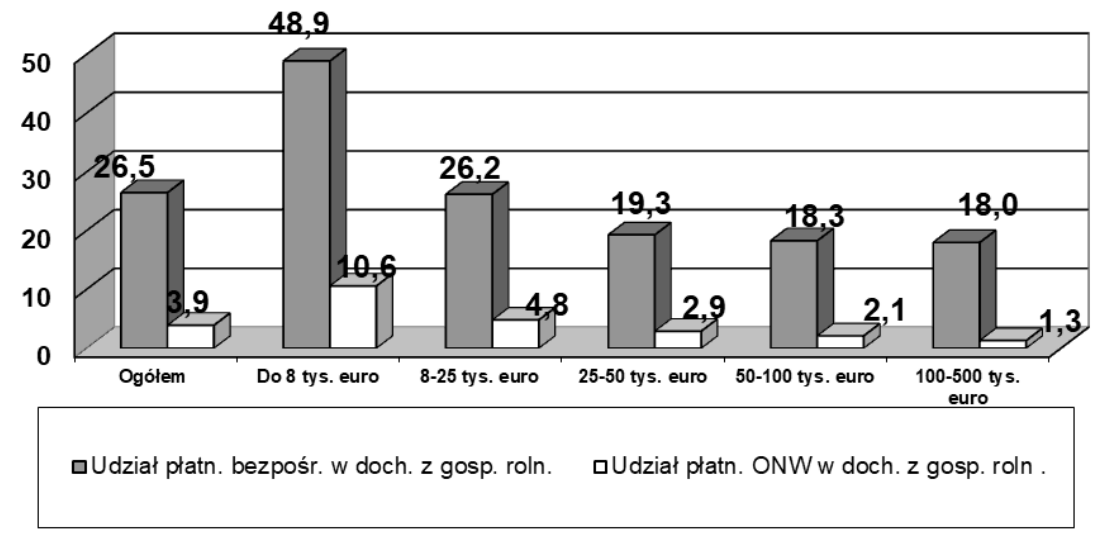

Rysunek 2. Udział płatności bezpośrednich i płatności ONW w dochodzie z gospodarstwa rolniczego według wielkości ekonomicznej w 2015 roku [w \%]

Źródło: obliczenia własne na podstawie Wyniki Standardowe 2015 uzyskane przez gospodarstwa rolne uczestniczące w Polskim FADN. IERiGŻ, Warszawa 2016, s. 51-57.

W gospodarstwach do 8 tys. Euro płatności bezpośrednie stanowiły 48,9\%. W kolejnych grupach wraz ze wzrostem wielkości ekonomicznej zakres oddziaływania płatności bezpośrednich na dochody rolnicze systematycznie malał. W gospodarstwach o wielkości ekonomicznej 8-25 tys. Euro wynosił on 26,2\% a w gospodarstwach o wielkości 50-100 tys. Euro odpowiednio 18,3\%.

W przypadku płatności z tytułu przynależności do obszarów o niekorzystnych warunkach gospodarowania największy ich udział w relacji do dochodu z gospodarstwa rolniczego występował w gospodarstwach o wielkości ekonomicznej do 8 tys. Euro $(10,6 \%)$. Zdecydowanie najsłabsze oddziaływanie płatności z tytułu ONW na wyniki ekonomiczne miały miejsce w przypadku gospodarstw o wielkości ekonomicznej 100-500 tys. Euro.

\section{Zakres pomocy finansowej środkami WPR UE według typu rolniczego}

Typ rolniczy stanowi jedno z kryteriów używanych dla charakteryzowania gospodarstwa rolnego we Wspólnotowej Typologii Gospodarstw Rolnych. Określany jest on na podstawie udziału poszczególnych działalności rolniczych w tworzeniu całkowitej wartości Standardowych Produkcji (SO) gospodarstwa. W zależności od pożądanego stopnia dokładności, typy rolnicze gospodarstw są dzielone na: 8 typów ogólnych, 17 typów podstawowych, 50 typów szczegółowych.

Analizowane gospodarstwa reprezentowały różne typy rolnicze. W próbie badawczej polskiego FADN dominującym typem gospodarstw były gospodarstwa o typie mieszanym. Ich udział wynosił 32,1\%. Na drugim miejscu pod względem liczebności znalazły się gospodarstwa dla których główną działalnością biorącą udział w tworzeniu wartości standardowej produkcji były uprawy polowe. Ten typ rolniczy stanowił $27,7 \%$ ogółu gospodarstw. Udział pozostałych typów rolniczych wynosił odpowiednio: krowy mleczne $-22,6 \%$, trzoda chlewna $-6,3 \%$, zwierzęta trawożerne $-4,2 \%$, uprawy trwałe - 
$3,5 \%$, uprawy ogrodnicze $2,9 \%$. Stosunkowo najmniejszą grupę $(0,7 \%)$ stanowiły gospodarstwa drobiarskie.

Poszczególne grupy gospodarstw wydzielone ze względu na typ rolniczy charakteryzowały się dużym zróżnicowaniem wyników produkcyjnych (tabela 2).

Tabela 2. Charakterystyka gospodarstw według typu rolniczego w 2015 roku

\begin{tabular}{|c|c|c|c|c|c|c|c|c|}
\hline Wyszczególnienie & $\begin{array}{l}\text { Uprawy } \\
\text { polowe }\end{array}$ & $\begin{array}{l}\text { Uprawy } \\
\text { ogrod- } \\
\text { nicze }\end{array}$ & $\begin{array}{l}\text { Uprawy } \\
\text { trwałe }\end{array}$ & $\begin{array}{l}\text { Krowy } \\
\text { mlecz- } \\
\text { ne }\end{array}$ & $\begin{array}{l}\text { Zwierz. } \\
\text { trawo- } \\
\text { żerne }\end{array}$ & $\begin{array}{l}\text { Trzoda } \\
\text { chlew- } \\
\text { na }\end{array}$ & Drób & $\begin{array}{l}\text { Mie- } \\
\text { szane }\end{array}$ \\
\hline Liczba gospodarstw & 3411 & 354 & 437 & 2782 & 522 & 776 & 89 & 3942 \\
\hline Powierzchnia UR w ha & 29,1 & 6,0 & 9,5 & 21,4 & 17,5 & 19,8 & 23,9 & 16,9 \\
\hline $\begin{array}{l}\text { Nakłady pracy ogółem } \\
\text { w AWU na } 1 \text { gospodar- } \\
\text { stwo }\end{array}$ & 1,53 & 2,62 & 2,13 & 1,80 & 1,40 & 1,56 & 3,24 & 1,62 \\
\hline Plony pszenicy w dt/ha & 62,2 & 50,1 & 45,0 & 48,8 & 48,2 & 56,5 & 51,2 & 55,0 \\
\hline $\begin{array}{l}\text { Wydajność mleczna } \\
\text { krów w litrach }\end{array}$ & 4568 & 2521 & 2417 & 5343 & 4297 & 3436 & 2900 & 5340 \\
\hline $\begin{array}{l}\text { Obsada zwierząt w LU/ } \\
\text { ha }\end{array}$ & 1,6 & 0,3 & 0,1 & 24,5 & 14,0 & 53,7 & 156,5 & 12,1 \\
\hline $\begin{array}{l}\text { Wielkość ekonomiczna } \\
\text { gospodarstwa w euro }\end{array}$ & 21327 & 44177 & 16545 & 30591 & 14923 & 51504 & 172745 & 19101 \\
\hline
\end{tabular}

Źródło: obliczenia własne na podstawie Wyniki Standardowe 2015 uzyskane przez gospodarstwa rolne uczestniczące w Polskim FADN. IERiGŻ, Warszawa 2016, s. 42-51.

Największą powierzchnią użytków rolnych odznaczały się gospodarstwa nastawione na uprawy polowe $(29,1$ ha). Istotną rolę odgrywał obszar w gospodarstwach, w których dominującą działalnością biorącą udział w tworzeniu ogólnej wartości standardowej produkcji był chów krów mlecznych (21,4 ha), trzody chlewnej (19,8 ha) i zwierząt trawożernych $(17,5$ ha). Stosunkowo najmniejszymi były gospodarstwa specjalizujące się w uprawach ogrodniczych. Średni obszar wynosił tutaj zaledwie 6,0 ha UR.

Typ rolniczy okazał się również czynnikiem różnicującym wyniki ekonomiczne gospodarstw (rysunek 3).

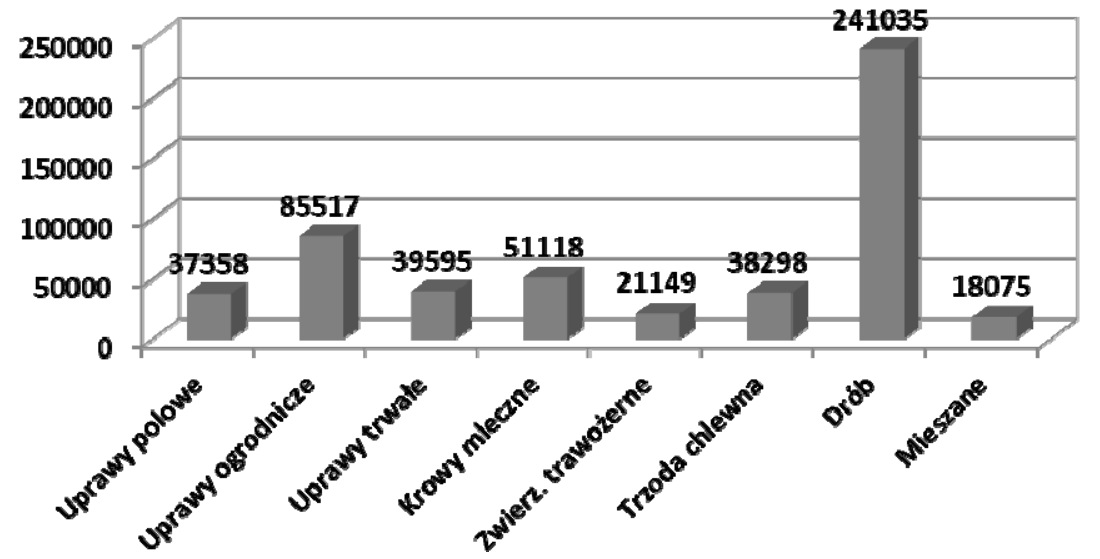

Rysunek 3. Poziom dochodu rolniczego według typów gospodarstw w roku 2015 [w zł]

Źródło: obliczenia własne na podstawie Wyniki Standardowe 2015 uzyskane przez gospodarstwa rolne uczestniczące w Polskim FADN. IERiGŻ, Warszawa 2016, s. 42-51. 
Najwyższym poziomem dochodu z gospodarstwa rolniczego wyróżniały się gospodarstwa trudniące się chowem drobiu i gospodarstwa ogrodnicze. Średni poziom tej kategorii dochodu w przeliczeniu na 1 gospodarstwo wynosił tutaj odpowiednio ponad 241,0 tys. zł i 85,5 tys. zł. Najsłabiej pod względem ekonomicznym w tym zestawieniu wypadały gospodarstwa o typie mieszanym. Ich dochód na 1 gospodarstwo wynosił w 2015 roku zaledwie 18,1 tys. zł.

Typ rolniczy różnicował także wielkość płatności bezpośrednich do gruntów rolnych analizowanych gospodarstw (tabela 3 ). Wynikało to ze zróżnicowania obszarowego gospodarstw oraz z różnego poziomu płatności stosowanych do powierzchni określonych roślin uprawnych.

Tabela 3. Wielkość wsparcia środkami WPR UE wedhug typów gospodarstw w roku 2013
\begin{tabular}{|l|c|c|c|c|c|c|c|c|c|}
\hline Wyszczególnienie & $\begin{array}{c}\text { Uprawy } \\
\text { polowe }\end{array}$ & $\begin{array}{c}\text { Uprawy } \\
\text { ogrod- } \\
\text { nicze }\end{array}$ & $\begin{array}{c}\text { Uprawy } \\
\text { trwałe }\end{array}$ & $\begin{array}{c}\text { Krowy } \\
\text { mlecz- } \\
\text { ne }\end{array}$ & $\begin{array}{c}\text { Zwierz. } \\
\text { trawo- } \\
\text { żerne }\end{array}$ & $\begin{array}{c}\text { Trzoda } \\
\text { chlew- } \\
\text { na }\end{array}$ & Drób & $\begin{array}{c}\text { Mie- } \\
\text { szane }\end{array}$ \\
\hline $\begin{array}{l}\text { w zł na 1 gospodarstwo } \\
\text { Płatności bezpośrednie } \\
\text { do gruntów rolnych }\end{array}$ & 13166 & 2726 & 4292 & 9720 & 7942 & 8954 & 10832 & 7672 \\
\hline Płatności z tytułu ONW & 1076 & 369 & 601 & 2014 & 1994 & 1327 & 1670 & 1162 \\
\hline $\begin{array}{l}\text { Płatności rolno- } \\
\text { środowiskowe }\end{array}$ & 1990 & 288 & 1540 & 920 & 3574 & 739 & 513 & 975 \\
\hline $\begin{array}{l}\text { Inne dopłaty do rozwo- } \\
\text { ju obszarów wiejskich }\end{array}$ & 1166 & 3486 & 736 & 1576 & 932 & 310 & 338 & 837 \\
\hline $\begin{array}{l}\text { Lącznie środki wypła- } \\
\text { cane w ramach WPR } \\
\text { UE }\end{array}$ & 17398 & 6869 & 7169 & 14230 & 14442 & 11330 & 13353 & 10646 \\
\hline
\end{tabular}

Źródło: obliczenia własne na podstawie Wyniki Standardowe 2015 uzyskane przez gospodarstwa rolne uczestniczące w Polskim FADN. IERiGŻ, Warszawa 2016, s. 42-51.

Najwięcej środków pochodzących z płatności bezpośrednich trafiła do gospodarstw specjalizujących się w uprawach polowych. W przeliczeniu na jedno gospodarstwo była to kwota 13166 zł. W gospodarstwach ogrodniczych średnia wielkość płatności wyniosła 2726 zł. Duże zróżnicowanie wynikało z wielkości obszarowej gospodarstw. Średni obszar gospodarstw należących do tych typów rolniczych wynosił odpowiednio 29,1 ha i 6,0 ha.

Wśród analizowanych gospodarstw największą kwotę płatności z tytułu ONW otrzymały te specjalizujące się w chowie krów mlecznych. Średnio na jedno gospodarstwo była to kwota 2014 zł. W przeliczeniu na jednostkę powierzchni wyniosła ona 94 zł. W gospodarstwach ogrodniczych płatność z tytułu ONW wyniosła średnio zaledwie 369 zł na 1 gospodarstwo i 61 zł na 1 ha.

Do analizowanych gospodarstw trafiały także dopłaty rolno-środowiskowe oraz dopłaty do rozwoju obszarów wiejskich. W pierwszym przypadku najwyższe kwoty płatności otrzymały gospodarstwa specjalizujące się w chowie zwierząt trawożernych (3574 zł), w drugim przypadku te nastawione na produkcję ogrodniczą (365 zł).

Zakres oddziaływania płatności bezpośrednich do gruntów rolnych oraz płatności z tytułu ONW na sytuację dochodową gospodarstw przedstawia rysunek 4. 


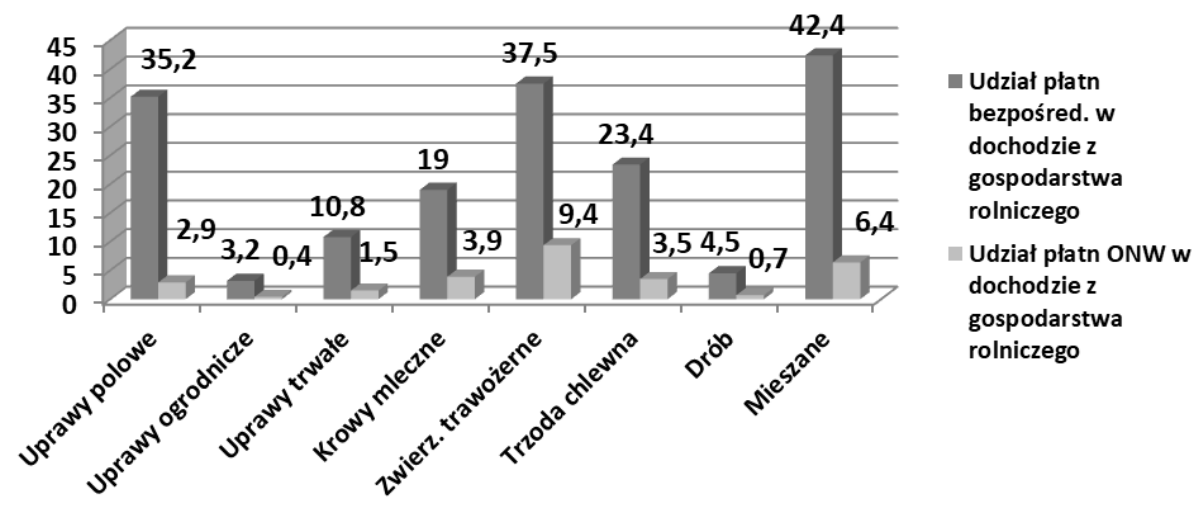

Rysunek 4. Udział płatności bezpośrednich i płatności ONW w dochodzie z gospodarstwa rolniczego w różnych typach gospodarstw w 2015 roku [w \%]

Źródło: obliczenia własne na podstawie Wyniki Standardowe 2015 uzyskane przez gospodarstwa rolne uczestniczące w Polskim FADN. IERiGŻ, Warszawa 2016, s. 42-51.

Najszerszy zakres oddziaływania płatności bezpośrednich na dochody rolników zaznaczył się w przypadku gospodarstw o typie rolniczym mieszanym i gospodarstw nastawionych na chów zwierząt trawożernych. Udział tej formy płatności w dochodzie $\mathrm{z}$ gospodarstwa rolniczego wynosił tutaj odpowiednio 42,4\% i 37,5\%.

Podobny zakres zależności występował także w przypadku płatności z tytułu przynależności do obszarów o niekorzystnych warunkach gospodarowania. Największy ich udział $\mathrm{w}$ relacji do dochodu $\mathrm{z}$ gospodarstwa rolniczego występował $\mathrm{w}$ gospodarstwach specjalizujących się w chowie zwierząt trawożernych i gospodarstwach o typie rolniczym mieszanym. Relacja ta kształtowała się na poziomie 9,4\% i 6,4\%.

Zdecydowanie najsłabsze oddziaływanie zarówno płatności bezpośrednich jak i płatności z tytułu ONW na wyniki ekonomiczne miało miejsce w przypadku gospodarstw ogrodniczych.

\section{Wnioski}

Reasumując dotychczasowe rozważania można sformułować następujące wnioski:

- Przystapienie Polski do UE oznacza dla polskiego rolnictwa znaczące wsparcie finansowe w ramach środków Wspólnej Polityki Rolnej. Ma ono bezpośredni wpływ na dochody gospodarstw rolniczych. W analizowanych gospodarstwach średnia wielkość tego wsparcia w 2015 roku wyniosła 12406 zł. Stanowiło to 37,5\% dochodu uzyskanego z gospodarstwa rolniczego.

- Podstawowymi elementami wsparcia ze środków WPR UE były płatności realizowane w ramach dopłat bezpośrednich i płatności dla obszarów o niekorzystnych warunkach gospodarowania. Stanowiły one w 2015 roku odpowiednio 70,7\% i 10,5\% ogólnego wsparcia.

- $\quad$ Istotnym elementem różnicującym kwotę środków przekazywanych w ramach WPR UE była wielkość ekonomiczna gospodarstwa. W odniesieniu do badanych gospodarstw obserwowano zależność, iż wraz ze wzrostem ich wielkości ekonomicznej 
zwiększeniu ulegała kwota przekazywanych płatności bezpośrednich jak i płatności z tytułu ONW.

- Czynnikiem różnicującym wielkość wsparcia środkami WPR UE okazał się także typ rolniczy. Największa wielkość środków pochodzących z płatności bezpośrednich trafiła do gospodarstw specjalizujących się w uprawach polowych. W przeliczeniu na jedno analizowane gospodarstwo w 2015 roku była to kwota $13166 \mathrm{zl}$. W gospodarstwach ogrodniczych średnia wielkość tej płatności była ponad 4,5-krotnie niższa. Najszerszy zakres oddziaływania płatności bezpośrednich na dochody rolników zaznaczył się w przypadku gospodarstw o typie rolniczym mieszanym oraz nastawionych na chów zwierząt trawożernych. Udział tej formy płatności w dochodzie z gospodarstwa rolniczego wynosił tutaj odpowiednio $42,4 \%$ i $37,5 \%$. Na te dwa typy gospodarstw przypadał także najsilniejszy zakres oddziaływania ze strony płatności z tytułu ONW.

\title{
Literatura
}

Florianczyk Z., Malanowska B, Osuch D., Bocian M., 2015: Opis realizacji planu wyboru próby gospodarstw rolnych dla Polskiego FADN w 2015 roku. IERiGŻ, Warszawa .

Frenkel I., 2013: Zatrudnienie i struktura dochodów w gospodarstwach rolnych w latach 205-2010. IRWiR PAN, Warszawa.

Informacja z realizacji zadań Agencji Restrukturyzacji i Modernizacji Rolnictwa w 2016 roku. Departament Analiz Działalności i Rozwoju ARiMR, Warszawa 2017.

Klimkowski C., Gruda M., 2016: Podział i transfer dochodów między rolnictwem a gospodarką narodową. Program Wieloletni 2015-2019 IERiGŻ, Warszawa,

Nurzyńska I., 2016,: Polska wieś i rolnictwo jako beneficjenci funduszy Unii Europejskiej. (w:) Polska wieś 2016. Raport o stanie wsi. Wydawnictwo SCHOLAR, Warszawa.

Wyniki Standardowe 2015 uzyskane przez gospodarstwa rolne uczestniczące w Polskim FADN. IERiGŻ, Warszawa 2016.

Zegar J.S. Chmielewska B., 2016: Dochody ludności wiejskiej: źródła, zróżnicowanie i zakres ubóstwa. (w:) Raport o stanie wsi. Polska wieś 2016. Wyd. Naukowe SCHOLAR, Warszawa.

\begin{abstract}
The aim of this paper is to illustrate the extent to which the level of support for farms is measured by means of the Common Agricultural Policy. A detailed analysis was made of direct payments and payments for less-favored areas (LFAs). Their size was considered in relation to farm income. The calculations were made using the method used in the European Farm Accountancy Date Network (FADN). The share of funds from the CAP in analyzed farms in relation to income in 2015 was $37.5 \%$. The economic size and agricultural type of the farm proved to be an important element in differentiating the level of farm support from the Common Agricultural Policy. The main elements of support from the EU CAP were payments made under direct payments and payments for less-favored areas. They accounted for $70.7 \%$ and $10.5 \%$ of total support respectively in 2015.
\end{abstract}

Key words: direct payments, differentiation, income from a farm, agricultural type. 
Informacja o autorach:

\section{Dr inż. Agata Marcysiak}

Katedra Ekonomii

Wydział Nauk Ekonomicznych i Prawnych

Uniwersytet Przyrodniczo-Humanistyczny w Siedlcach

ul Żytnia 17/19

08-110 Siedlce

admamar@poczta.onet.pl

Dr inż. Adam Marcysiak

Katedra Logistyki

Wydział Nauk Ekonomicznych i Prawnych

Uniwersytet Przyrodniczo-Humanistyczny w Siedlcach

ul Żytnia 17/19

08-110 Siedlce

admamar@poczta.onet.pl 